\title{
Inland Water Transport and Urban Mobility in Ikorodu-Ebutte Ero Route, Lagos, Nigeria
}

\author{
Usman Bolaji Abdulkadir* and Animashaun Kikelomo Halimat \\ Department of Geography and Environmental Management, Faculty of Social Sciences, \\ University of Ilorin, PMB 1515, Ilorin, Nigeria \\ *Corresponding Author: usman.ba@unilorin.edu.ng
}

Received 3 December 2019/ Revised 25 March 2020/ Accepted 14 April 2020/ Published 27 April 2020

\begin{abstract}
Lagos city has abundant navigable inland waterways which if fully harnessed would help minimise road traffic congestion, pollution and provide low cost means of long distance travel within the city. This study examines inland water transport services on Lagos lagoon focusing on Ikorodu-Ebutte Ero route. Primary data were obtained using structured questionnaires. While, secondary data were sourced from relevant government and private agencies. Data were analysed using descriptive techniques including frequency counts, tables and graphs. The results revealed an inadequate provision of terminal facilities and vessels in the area. It was also found that most $(67.3 \%)$ of the trips via water transport in the were mainly for work purpose. In addition, low patronage was observed and it was found to be mostly due to comparatively high cost of fares and passenger safety concerns, as indicated by $67.4 \%$ and $58.7 \%$ of the respondents respectively. Furthermore, high income earners where found to patronise this mode than low income earners. The high frequency of use of water transport by the respondents ( $71.3 \%$ travel by water every day) indicates that, this mode has great potential of being widely adopted, if greater attention is given to its development by both the government and private sector. There is, therefore, a need for more investment in water transportation in the area through the provision of modern infrastructure and vessels.
\end{abstract}

Keywords: urban mobility; inland waterways; transport services; sustainable transportation; integrated transport.

\section{Introduction}

Modern cities are highly transport dependent and this makes it essential for cities to develop efficient transportation systems that provide effective links within the city and for both the national and global transportation systems (Hoyle, 1993; Kurniasari et al., 2018). A side from being the oldest means of transporting goods and services, inland waterways have been associated with facilitation of commerce, provision of employment and wealth creation among many other benefits (Gray, 2004; Fellinda, 2006; Christodoulou et al., 2019; Dai et al., 2019; Wiercx et al., 2019; Tanko et al., 2019; Hossain et al., 2019). Looking back to the period of the industrial revolution in Europe, waterways played an essential role. They served 
as initial corridors of transportation and many of them eventually became important areas of commerce and industrial development. Several cities of the industrial revolution era (such as Oslo, Hamburg and Liverpool among others) had most of their industrial and commercial activities located close to the waterfronts. However, from the mid- $20^{\text {th }}$ century, the importance of waterborne transport declined significantly with the increasing development of motorways and the associated inland urban sprawl development (International Association of Public Transport, 2013).

However, in the recent years, increasing congestion on urban roads has directed attention to the development of other more sustainable forms of transportation. In addition, the fact that efficient transportation systems serve as catalyst for sound land use planning is increasingly being recognised. Both of these reasons have provided an opportunity for water transport to play more significant role in urban mobility schemes in many parts of the world (International Association of Public Transport, 2013). Water transport provides the opportunity for improving urban transportation by helping to provide faster (hardly experienced congestion), more efficient and better integrated transport services for the urban area (Hoyle, 1993).

Nigeria has about 8,600 kilometres of inland waterways and an extensive area of coastland of over 800 kilometres (Ndikom, 2013). Up to early 1960s, inland waterways provided important routes for access from the coast to the hinterland and accounted for more than $30 \%$ of the total produce transported in the country. However, by the late 1960 s the significance of this important means of transportation had declined. At present only about 3,000 kilometres of the country's inland waterways is being harnessed (Badejo, 2011). Although, water transport is known to be comparatively cheaper and most efficient for riverine communities, this mode of transport is currently highly neglected and undervalued in the country (Ndikom, 2013; Adejare et al., 2017).

Lagos, the commercial capital of Nigeria has been observed to possess the necessary inland waterway network capacity to transport commuters to most parts of the city, but the waterways are grossly under utilized. The existing water transport facilities are inadequate both in terms of size and access to commuters (Adejare et al.,2017; Ogunbajo et al., 2017). Ademiluyi et al., (2016) also observe that in spite of the numerous merits of water transport such as the low cost, larger capacity and safety, this mode of transport is yet to be fully tapped to achieve the potential benefits it possesses. They, therefore, called for more attention to water transportation in the State, in terms of greater investment through public or private partnership. It has also been noted that the Lagos State Government's 30 year transportation 
improvement plan of integrating the Bus Rapid Transit (BRT) with light rail schemes may not solve the congestion problem, except it also incorporatesthe water transport mode (Edelman, 2015).

The improvement of water transport in Lagos has the potential to help address the serious road congestion and its associated problems such as extended travel time, loss of man hour, and negative effects on the environment and human health. If well-developed, water transport would help improve mobility since it could easily be organized to have fixed travel time because it hardly experiences congestion (Bayode \& Ipingbemi, 2016; Tobias et al., 2019; Tannum \& Ulvensøen, 2019; Iamtrakul \& Wongbumru, 2019; Łapko \& Panasiuk, 2019; Iamtrakul, 2018). Focusing on water transport is important and relevant in Lagos, because of its high potential for developing this mode of transport. It is also more economical and sustainable compared to road transport. This is because, in the long run, it entails less financial investment since it requires less maintenance and has higher capacity for passengers and goods.

Although some other studies (Adejere et al., 2011; Ademiluyi et al., 2016; Ogunbajo et al., 2017) have been carried out on inland water transport in Lagos State, this study is different from the previous ones because it specifically focuses on the Ikorodu-Ebutte Ero route. This study also adopts both quantitative and qualitative methods essential for an indepth examination of activities on the Lagos waterways. This study examines the operation of inland water transport along the Ikorodu-Ebute Ero route in Lagos City, with a view to recommend strategies for raising its capability as a mode of transportation in the area. The specific objectives are to: examine the available water transport facilities; determine its contributions to passenger movement; examine the characteristics of the passengers; as certain the problems associated with use of water transport; and to suggest possible strategies to improve water transportation in the area.

\section{Area of Study}

Lagos state is located between Longitude $2^{0} 42^{\prime}$ East and $3^{0} 42^{\prime}$ East and Latitude $6^{0}$ $22^{\prime}$ North and $6^{0} 52^{\prime}$ North, in the Southwestern Nigeria. It occupies an area of 3,475.1 $\mathrm{km}^{2}$ with $22 \%$ of the total land area consisting of creeks and lagoons. It lies entirely within the coastal plain and the land does not rise over $650 \mathrm{~m}$ above the sea level. Most of its land area lies below $320 \mathrm{~m}$ above sea level and this subjects most of the areas to floods and beach erosion. 
According to the 1991 national census the State had a population of 5,725,116, which had increased to $9,113,605$ by 2006 . The population was estimated to have risen to 11 million by 2011 and to 12.5 million in 2016 (Nigerian Bureau of Statistics (NBC), 2008 and 2013). The city's metropolitan area which had a population of only 290,000 in 1950 is now estimated to have a population of over 12 million and it is expected to grow to be the world's third largest city by 2050 .

Seventeen out of the twenty Local Government Areas (LGAs) in the State fall within the metropolis while twelve LGAs encompass riverine communities (Figure 1). Lagos State operates 12 ferry routes under the supervision of Lagos State Water Authority (LASWA). The routes as identified by Ademiluyi (2016), Bayode \& Ipingbemi (2016) are IkoroduMarina/CMS; Marina-Mile 2; Ikorodu-Addax/Falomo; Ikorodu-EbuteEro, MarinaIjegunEgba-EbuteOjo; Mile 2-Marina/CMS-Mekwen-Falomo; Badore-Ijede; Badore-Five Cowries; Marina- Oworonshonki; EbuteOjo-IjegunEgba; Oworonshonki-Five Cowries; and Baiyeku- Langbasa.

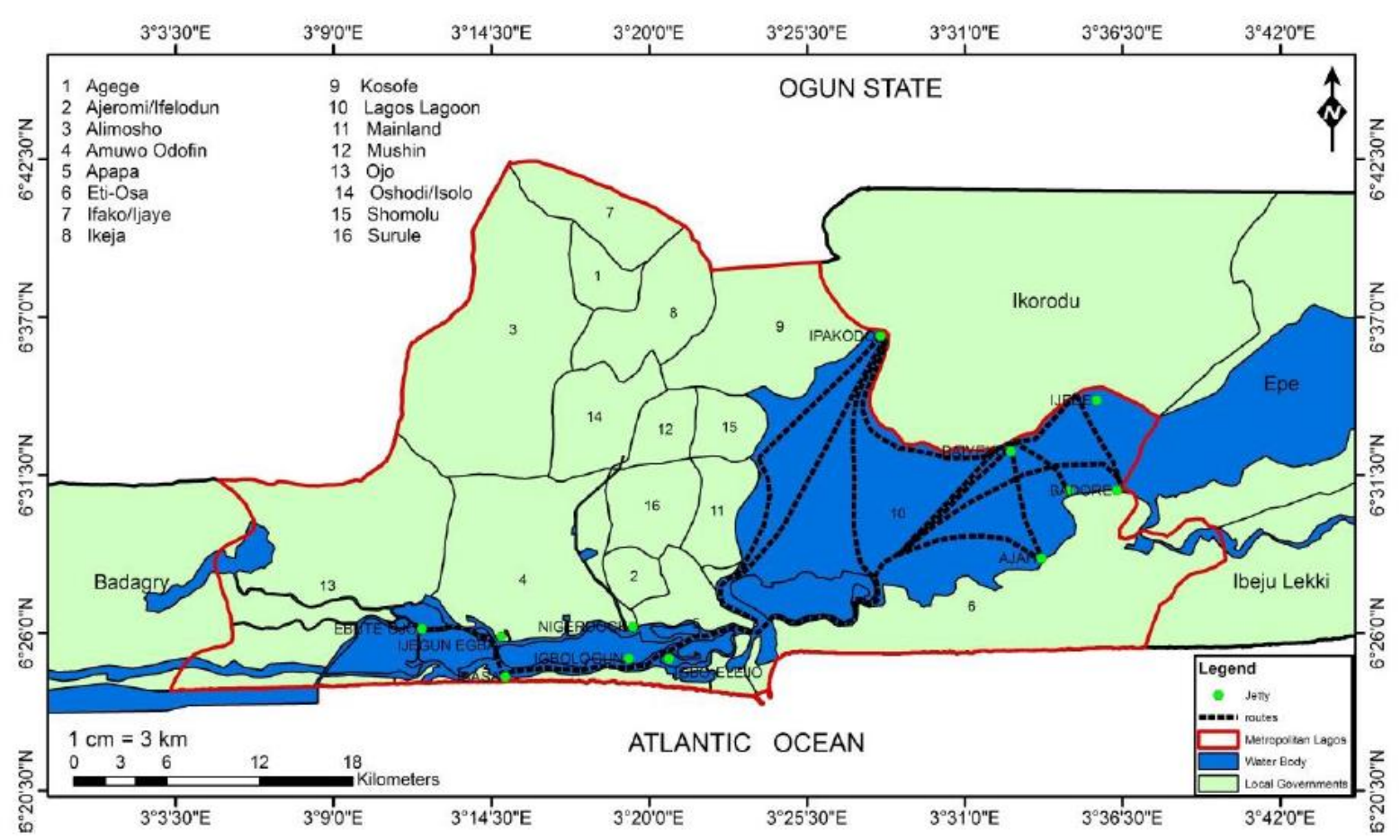

Figure 1. Lagos Inland Waterways Routes

Transportation in the study area is mostly by road which accounts for about $90 \%$ of traffic flow in the area. Despite the abundance of waterways in Lagos, waterborne transport is not as popular as road transport to get around the city. Apart from the few regular ferry 
services between Lagos Island and the Mainland, fibre-covered motorised boats and canoes also operate passenger services on the lagoon and some of the creeks.

\section{Methods}

Data used for this study include data on available water transport facilities, socioeconomic and travel characteristics of the passengers, passenger movement and challenges militating against the development of inland waterways in the area. Secondary data were obtained from transport departments of riverine Local Government Areas. Official data were also obtained from the Lagos State Ministry of Works and Transport, Lagos Metropolitan Area Authority, Lagos Water Authority and Lagos Ferry Corporation.

Primary data were obtained through questionnaire survey using two types of questionnaire. Questionnaire (A) was used to derive information from the Union officials of vessel operators at the two operational jetties in the area, Association of Tourist Boat Operators of Nigeria (ATBOWNATION) and Sea Coach water Transport Union. The data included number, types and capacity of vessels and number of trips made per day. Other jetties in the area which are Ikorodu Terminal (Operated by Lagos State Government) and Metro Ferry Water Transport were not in operation at the time of the survey. Questionnaire (B) was used to gather information from users of water transport services. After it was estimated through a reconnaissance survey that about 3,000 passengers are transported through the two sampled jetties per day, five percent (150) of the passengers were sampled for the study. This is at 7.8 margin of error and $95 \%$ confidence level. Systematic random sampling was used to select the passengers on whom the questionnaire was administered.The questionnaire survey was conducted with the aid of four research assistants who were adequately trained for the survey. The data collected were analysed using descriptive techniques including frequency counts, tables and graphs.

\section{Results and Discussion}

4.1 Water Transport Facilities Available in the Area

There are four jetties at Ikorodu area of Lagos state. These are the Ikorodu terminal Jetty (owned by the Lagos State Government), Association of Tourist Boat Operators and Water Transporter of Nigeria (ATBOWNATION) Jetty, Metro Ferry Water Transport Jetty and Sea Coach Water Transport Jetty (all privately owned). However, only two of them; ATBOWNATON and Sea Coach Water Transport Jetties were functional at the time of the study in June 2017. The main consequence of inadequate number of operational jetties in the 
area is that people were greatly restricted from accessing water transport mode in the area. The ATBOWNATON jetty had a total of 56 vessels while Sea Coach jetty had 13 vessels operating from it as shown in Table 1.

Table 1. Available water transport vessels in the area

\begin{tabular}{ccc}
\hline Name of jetty & Number of vessels & Capacity of vessels \\
\hline ATBOWNATION Jetty & 56 & 20 \\
Sea Coach : & & 2 \\
1. Shutter & 1 & 31 \\
2. Cruiser & 2 & 35 \\
3. Coaster & 10 & 88 \\
\hline Total & 69 & \\
\hline
\end{tabular}

As also shown in Table 1, the vessels are of different capacity and quality. While the ATBOWANATION use standard vessels of 20 passenger capacity, Sea Coach jetty operators use a variety of vessels with capacity between two to 35 passengers. Most of the vessels were fibre covered locally manufactured vessels while a few were imported standard vessels which were more expensive.

An examination of other supporting facilities in the area covered the car parking facilities, passengers' lounge and other facilities. For instance ATBOWNATON jetty has a car parking facility with the capacity of 80 cars while the Sea Coach's facility has a capacity of 50 cars. The Sea Coach jetty has other facilities such as restaurant and restrooms which were not available at ATBOWNATON jetty (Table 2).

Table 2. Other facilities at the jetty area

\begin{tabular}{lcc}
\hline \multicolumn{1}{c}{ Facilities } & $\begin{array}{c}\text { Condition of facilities at sea } \\
\text { coach jetty }\end{array}$ & $\begin{array}{c}\text { Condition of facilities } \\
\text { atbownation jetty }\end{array}$ \\
\hline $\begin{array}{l}\text { Car Park capacity } \\
\text { Passenger' lounge }\end{array}$ & 50 cars & 80 cars \\
capacity & 40 passengers & 50 passengers \\
Jetty structure & Wooden & Wooden \\
Other facilities & None & Restaurant and rest rooms \\
\hline
\end{tabular}

\subsection{Contributions of Inland Water Transport to Passengers Movements in the Area}

The study further examined the impact of water transport on movements of the people in the study area. The average number of passengers moved per day was estimated using the number and capacity of available water vehicles and the average number of trips made per day. It was found that on average, up to 2,842 passengers were transported by water per day along the Ikorodu - Ebutte-Ero axis of Lagos State (Table 3). 
Table 3. Average number of passengers moved per day

\begin{tabular}{lcccc}
\hline \multicolumn{1}{c}{ Operators } & $\begin{array}{c}\text { Number of } \\
\text { vessels }\end{array}$ & $\begin{array}{c}\text { Capacity of } \\
\text { vessels }\end{array}$ & $\begin{array}{c}\text { Average } \\
\text { trip per day }\end{array}$ & $\begin{array}{c}\text { Total number } \\
\text { of passengers } \\
\text { per day }\end{array}$ \\
\hline ATBOWNATION & 56 & 20 & 2 & 2240 \\
Sea Coach : & 1 & 2 & 2 & 4 \\
1. Shuttle & 4 & 31 & 2 & 248 \\
2. Cruiser & 10 & 35 & 1 & 350 \\
3. Coaster & \multicolumn{1}{c}{ Total } & & & 2842 \\
\hline
\end{tabular}

Table 3 shows that ATBOWNATION jetty had a high number of passengers movement because of its larger number of water vessels (56) compared to the 15 vessels at Sea Coach jetty. In addition, the ATBOWNATION jetty had a bigger car park, larger waiting room and a restaurant as other facilities that could be attracting more passengers. It could however be deduced that the low number of passengers moved could not be adduced to shortage of vessels, but may be explained by a problem of low patronage. The fact that the vessels do not make more than two trips per day is a clear evidence of this problem.

\subsection{Characteristics of Water Transport Passengers in the Area}

\subsubsection{Socio-Economic Characteristics}

Majority $(68 \%)$ of the respondents were found to be males. The preponderance of males among the passengers may be because males were more likely to take risk than females as travelling by water was perceived to be more dangerous than by road in Nigeria. The long term neglect of water transport by successive governments has been observed to be responsible for travel safety concerns among the people (Adeniyi, 2017). It was also found that most of the passenger fell within the middle aged group. For instance, $75.6 \%$ were between $26-45$ years, while $58 \%$ of the passengers were married. In addition, a very high proportion (96.7\%) of the respondents had secondary education and higher (Table 4). This indicates that most of those who patronise water means of transport in the state were educated. Furthermore, most $(84 \%)$ of the passengers were employed with about $60 \%$ of them earning at least $\mathrm{N}-80,000$ per month. 
Table 4. Social-Economic characteristics of respondents

\begin{tabular}{|c|c|c|c|}
\hline Characteristics & Characteristics & Frequency & Percentage \\
\hline \multirow{5}{*}{ Age } & $18-25$ & 5 & 3.3 \\
\hline & $26-35$ & 66 & 44 \\
\hline & $36-45$ & 47 & 31.3 \\
\hline & 46 and above & 32 & 21.3 \\
\hline & Total & 150 & 100 \\
\hline \multirow{5}{*}{ Marital status } & Single & 46 & 30.7 \\
\hline & Married & 87 & 58 \\
\hline & Separated & 5 & 3.3 \\
\hline & Divorced & 4 & 2.7 \\
\hline & Widowed & 8 & 5.3 \\
\hline \multirow{5}{*}{$\begin{array}{l}\text { Level of } \\
\text { education }\end{array}$} & No formal education & 5 & 3.3 \\
\hline & Primary education & - & - \\
\hline & Secondary education & 8 & 5.3 \\
\hline & Tertiary education & 83 & 55.3 \\
\hline & Others & 54 & 36 \\
\hline \multirow{7}{*}{ Occupation } & Private sector & 73 & 48.7 \\
\hline & Self employed & 29 & 19.3 \\
\hline & Government worker & 24 & 16 \\
\hline & Apprentice & 0 & 0 \\
\hline & Student & 10 & 6.7 \\
\hline & Unemployed & 13 & 8.7 \\
\hline & Others & 1 & 0.7 \\
\hline \multirow{6}{*}{$\begin{array}{l}\text { Monthly } \\
\text { income }\end{array}$} & Below $¥ 18,000$ & 9 & 6 \\
\hline & $\$ 18,000-N 49,000$ & 21 & 14 \\
\hline & $\$ 50,000-\$ 79,000$ & 24 & 16 \\
\hline & $¥ 80,000-\$ 109,000$ & 27 & 18 \\
\hline & $¥ 110,000$ and above & 61 & 40.7 \\
\hline & No Reponses & 8 & 5.3 \\
\hline
\end{tabular}

\subsubsection{Travel Characteristics}

The study also examines the travel characteristics of the respondents in the study area such as passengers preferred means of water transport, regularity of use of water transport and purpose of trip of the passengers among others.

\subsubsection{Preferred Type of Vessel}

This involved the examination of the respondents most preferred means of water transport among canoes, non-covered motorised vessels, fibre covered motorised vessels and ferry.

Results show that as high as $71.3 \%$ of the respondents preferred fibre covered motorised vessels while none of the respondents used canoe as shown in Table 5. The 
preference for fibre-covered motorized vessel by majority of the respondents as shown in Table 5 was expected because, it was faster and cheaper than other water vehicles in the area. Meanwhile the preference for ferry by significant proportion of the respondent $(23.3 \%)$ was because of its safety and better comfort when compared to the other available vessels.

Table 5. Travel characteristics of the respondents

\begin{tabular}{|c|c|c|}
\hline Characteristics & Frequency & Percentage \\
\hline \multicolumn{3}{|l|}{ Preferred vessel type } \\
\hline Canoes & 0 & 0 \\
\hline Non-covered Motorised vessel & 0 & 0 \\
\hline Fibre-covered Motorised vessels & 107 & 71.3 \\
\hline Ferry & 35 & 23.3 \\
\hline No response & 8 & 5.3 \\
\hline Total & 150 & 100 \\
\hline \multicolumn{3}{|l|}{ Regularity of travel by water } \\
\hline Everyday & 107 & 71.3 \\
\hline At least once a week & 10 & 6.7 \\
\hline At least once a month & 7 & 4.7 \\
\hline Occasionally & 19 & 12.7 \\
\hline No respond & 7 & 4.7 \\
\hline \multicolumn{3}{|l|}{ Purpose of trip } \\
\hline Commerce and shopping & 27 & 18.0 \\
\hline Education & 0 & 0 \\
\hline Family and social purposes & 14 & 9.3 \\
\hline Work & 101 & 67.3 \\
\hline Others & 0 & 0 \\
\hline No response & 8 & 5.3 \\
\hline \multicolumn{3}{|l|}{ Duration of journey } \\
\hline Less than 15 minutes & 17 & 11.3 \\
\hline $15-30$ minutes & 57 & 38.0 \\
\hline 31-45 minutes & 69 & 46.0 \\
\hline 46 mins- 1 hour & 0 & 0 \\
\hline Above 1 hour & 0 & 0 \\
\hline No response & 7 & 4.7 \\
\hline \multicolumn{3}{|l|}{ Cost of journey } \\
\hline Less than 200 & 0 & 0 \\
\hline$¥ 200-\cong 500$ & 0 & 0 \\
\hline N501- 700 & 91 & 60.5 \\
\hline$¥ 701-¥ 1,000$ & 53 & 35.3 \\
\hline Above 1,000 & 0 & 0 \\
\hline No response & 6 & 4.0 \\
\hline
\end{tabular}




\subsubsection{Regularity of Travel by Water Transport}

Regardingthe regularity of use of water transport by the respondents, it was found that $71.3 \%$ of them travelled by water transport everyday. Meanwhile, another $6.7 \%$ used it at least once a week as shown on Table 5.

\subsubsection{Purpose of Trips}

An examination of the purpose of trips shows that $67.3 \%$ of the respondents depended on water transport to travel to work, while $18 \%$ of the respondent's used water transport for commercial and shopping journeys as also shown on Table 5. Most (71.3\%) of the respondents were found to use water transportation on daily basis (Table 5).

\subsubsection{Duration of Journey}

The results further show that $46 \%$ of the respondents spent $31-45$ minutes on their journey while the duration of trip for $11.3 \%$ was less than 15 minutes per trip as shown on Table 5. It could be seen that travel time by water in the area was shorter than by road.

\subsubsection{Cost of Trips}

The monetary cost of trips incurred by passengers who travelled by water was however found to be higher than that of road transport. For instance it was found that $60.7 \%$ of the respondent paid $\$ 500$ - $\$ 700$ per trip, while $34.7 \%$ of them incurred between $\$ 701$ to ₹1000 per trip as also shown in Table 5.

\subsection{Problems Associated with Use of Water Transport in the Area}

The users of inland water transport in the area faced some challenges associated with their usage of water transport in the area. They indicated problems such as inadequate number of water vessels, poor quality of vessels, lack of adequate security and inadequate safety equipment among others.

\subsubsection{Insufficient Number of Water Vessels}

The study found that as high as $68 \%$ of the respondents opined inadequate supply of vessels as a problem militating against the development of water transportation in the area as shown in Figure 2. As a result intending passengers often had to join long queues at the jetties to get on boats or ferries. 


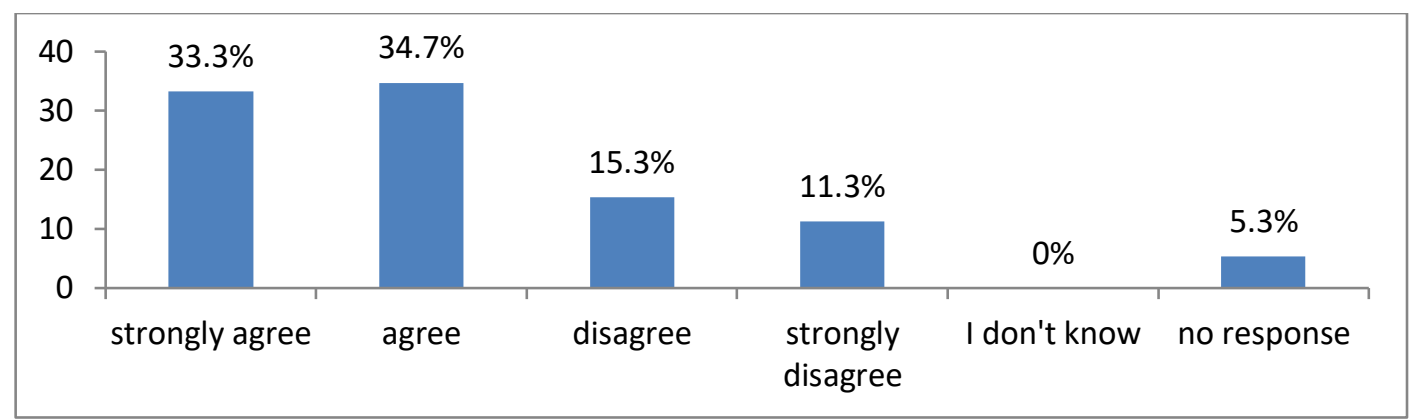

Figure 2. Respondents' opinion on inadequate number of water vessels as a problem

\subsubsection{Poor Quality of Vessels}

The results show that a high proportion of the respondents $(62.6 \%)$ held an opinion that most of the vessels were of poor quality while $14.7 \%$ of the respondents strongly disagreed that poor quality of vessels was a problem of water transport in the area as shown in Figure 3.

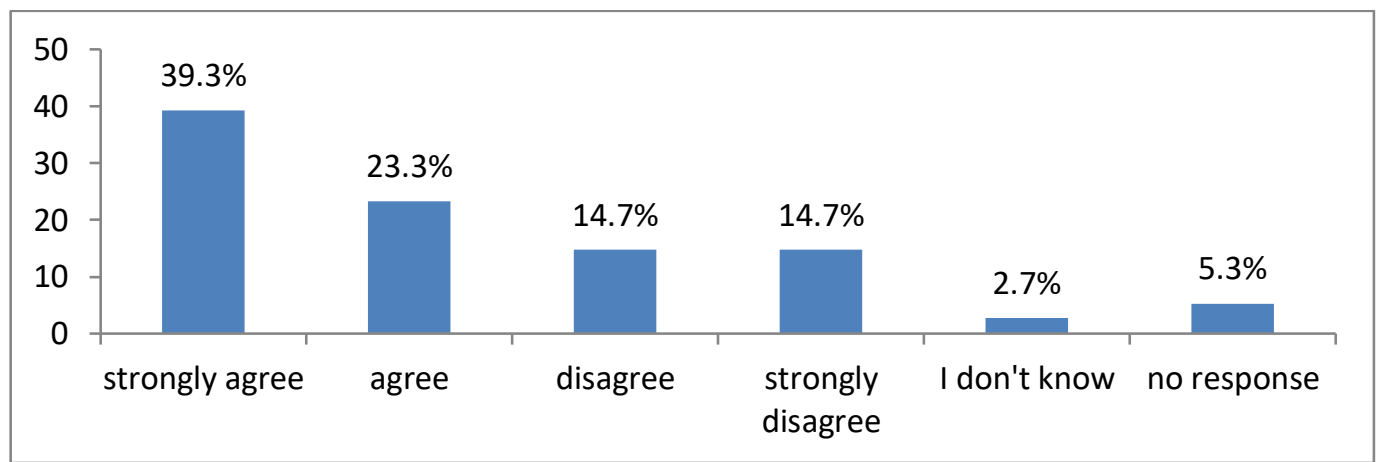

Figure 3. Respondents' opinion on poor quality of vessels as a problem

\subsubsection{Inadequate Security}

Inadequate security was seen to be a problem by $61.3 \%$ of the respondents as seen in Figure 4. As a feed transport mode that did not provide door to door service, it required passengers using other modes of transport to get to the jetty from home. This may require people toparktheir personal cars at the jetty car park for the duration of office hours.

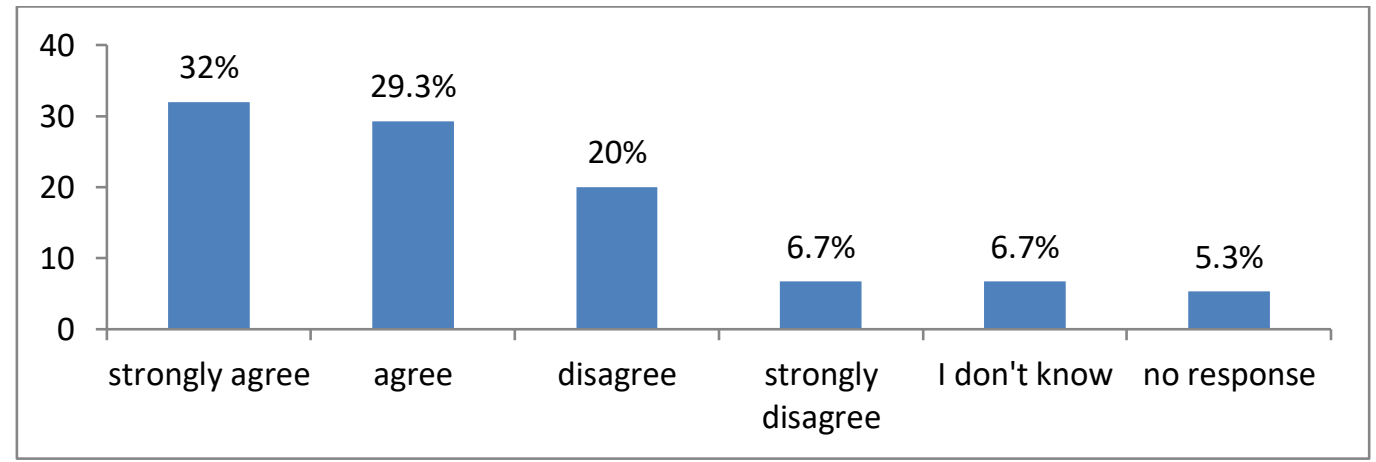

Figure 4. Respondents' opinion on inadequate security as a problem 


\subsubsection{Inadequate Transport Safety}

Results show that $58.7 \%$ of the respondents perceived transport safety as a problem of water transport in the area (Figure 5). The main issues related to safety raised by the people included inadequate safety equipment particularly life jackets, poor boat condition and reckless driving by the operators.

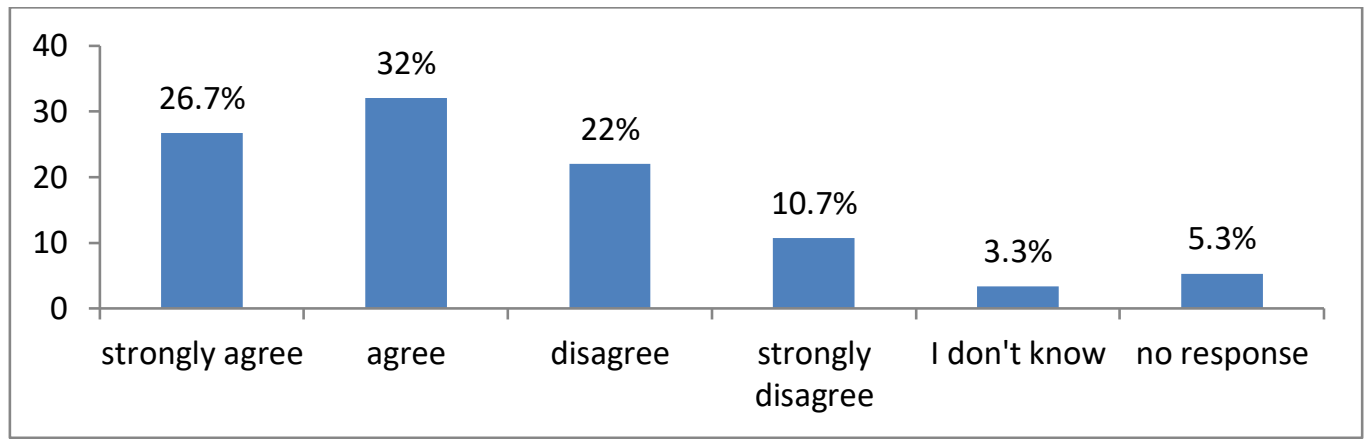

Figure 5. Respondents' opinion on transport safety as a problem

\subsubsection{High Cost of Transport}

Cost of transport was seen as a problem by as high as $67.4 \%$ of the respondents, as seen in Figure 6.For instance, a trip that would normally cost about $\$ 300$ by road cost would cost between $\$ 500$ - $\$ 700$ by water.

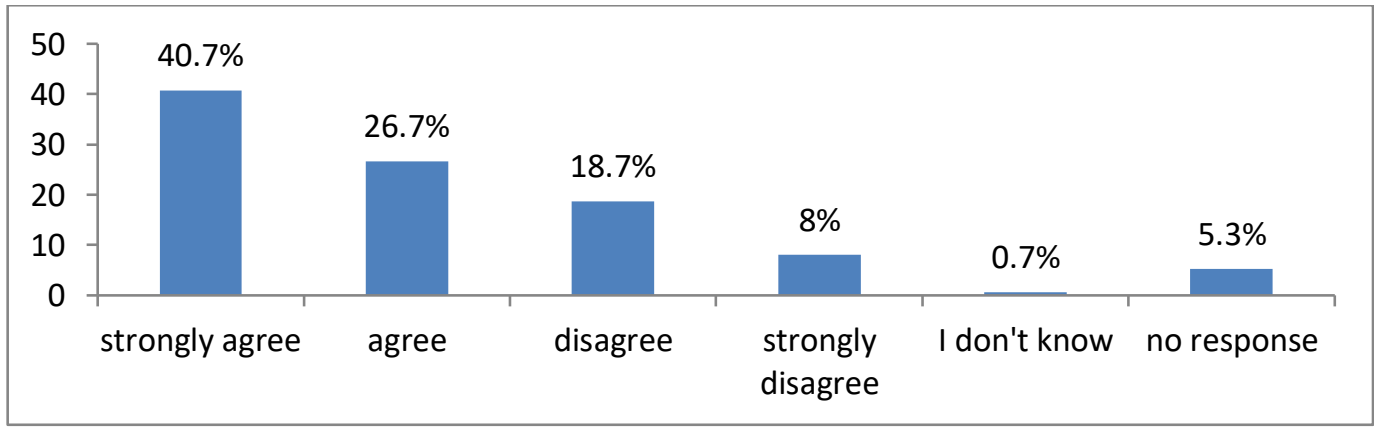

Figure 6. Respondents' opinion on high cost of transport as a problem

The results indicate that there was a gross inadequacy of terminal facilities and vessels for water transportation in the area. With only two out of five terminals in operation, the capacity of water transport to facilitate movements in the area had been greatly reduced. This was because access to this mode was denied or made difficult for many people in the area. In addition, the availability of other supporting facilities was very important because these could attract or discourage prospective passengers. This was in line with the findings of Chukwuma (2014); Bassey \& Nsa (2018) who noted that inadequate water transport facilities was a major factor impeding the development of inland water transport in Nigeria. For 
instance, the adequately available car parking facilities allows people with personal cars to keep their cars safe while travelling by boat on a part of their trips, thereby avoiding traffic stress on Lagos roads.

On the daily basis, water transport contributed to the mobility of almost 3,000 people within the Ikorodu-Ebute Ero axis of Lagos City (see Table 3). This was very low considering the hundreds of thousands of Lagos commuters who continued to travel by road on daily basis. This was an evidence that the potential of water transport had remained mostly untapped in the area. This was in line with the observation of Ademiluyi et al. (2016); Bayode \& Ipingbemi (2016) that water transport moves only a small proportion of the total traffic in Lagos State. However, while the number of commuters travelling by water in the area waslow,one should still appreciate the fact that these were people that would have added to the road traffic chaos in the area, either as public transport or personal cars passengers. Improved access is therefore a major issue that needs to be addressed to maximise the utilisation of water transportation in the area.

The two most preferred water vessels in the area were fibre-covered motorised vessels and ferries (Table 5). The preference for fibre-covered motorised vessel by the commuters was expected because; it was faster than other water vehicles in the area. Meanwhile, the preference for ferry was because of its safety and better comfort when compared to the other available vessels. This implies that the potential of this modes as an alternative to road transport will be greatly increased if more of these modern vessels are introduced into service in the area.

The consistency in the use of water mode of transportation by most $(71.3 \%)$ of the commutersusing this mode as seen in Table 5 is a further indication of the great potentials of water transport in the city. This also in line with the findings of Ademiluyi et al. (2016) who found a consistency in the use of water transport by most of the commuters traveling by water in Lagos city. This further indicates that the patronage of water transport would likely increase with the provision of more jetties andother supporting infrastructure such as car parks that will provide more access to a larger number of people in the area.

Most of the trips via water transport in the area were based on work purpose. Based on the Urban Transportation modelling system (UTMS) (Flugel \& Flotterod, 2015) categorisation ofthe purpose of trip in the area into trip distribution based on origin and purpose, majority of the respondents fell within the home-work category. On the average travel to work by road in Lagos took not less than 2-3 hours because of the prevalent traffic congestion. This resulted in Lagos being regarded as the city with the highest level of road 
traffic congestion in Nigeria. Therefore, travelling by water at least part of the trip, allows commuters to avoid traffic congestion and reduces travel time though at higher financial cost.

The higher rates charged per tripcompared to road travel can be attributed to the near monopoly enjoyed by the few private water transport operators. This is in line with the findings of Ogunbajo et al. (2017) who also noted that high cost of travel is amajor problem of water transportation in Lagos city. However, while on the surface it may seem more expensive because it implies substituting higher monetary cost for time, in the real sense it is more economical for the city because of the significant man-hour loses attributed to traffic congestion in Lagos City. For instance, it was estimated that Lagos commuters spent an average of 30 hours on traffic per week which was $75 \%$ of weekly working hours (Business Day Online, 2018). However, for the fact that most of water transport users were of the high income earners, it can be deduced that the cost of transport likely plays a significant role in people's decision to travel by this mode. The implication is that road travel may still continue to attract more Lagos commuters because of the relatively lower rates charged.

Most of the problems associated with the use of water transport in the area are direct result of poor level of investment in this mode of transport. The long term neglect of inland water transport by successive governments has led to the handover of themode of transportto the hands of few private individuals and enterprises. The high cost of acquisition and maintenance of vessels became a major restriction to entrance into this line of business. This was largely responsible for the inadequate supply in the sector. For instance, a locally manufactured 15 seater open (without roof) motorised vessel cost between $\$ 200,000$ $\$ 300,000$ depending on whether it was made of wood or fibre (Nwakunor et al., 2016). Although, the wooden boats weremore common because of their lower cost, they were still not affordable to many people who may be interested in joining the business in the area.

The poor quality of water vessels in the area was another evidence of the low level of development of this mode of transportation, particularly, when compared to road transport. This was another important factor that may discourage prospective passengers. For instance, while most of the boats were without roof (passengers were exposed to the elements), passengers also often had to sit on wooden planks with no backrest. Only the roofed fibrecovered boats and ferries were equipped with comfortable chairs while also providing protection from the sun/rain. Exposure to rain in particular has been observed to be a major complaint of water transport passengers in Lagos (Nwakunor et al., 2016). This is not surprising since it will be a serious discomfort to be soaked by rain while commuting to and from the office or school. 
While piracy was not identified as a problem to inland water transport in the area, traffic robberies, theft and other vices were known to be common around Lagos jetties due to the presence of touts and other miscreants within and around their vicinity. Therefore, passengers were sometimes exposed to some of these problems, such as breakage of their parked cars resulting in loss of valuables. In addition, operation of inland water transport in the area was largely dominated by informal business units and individual operators who wereoften uneducated, rash and aggressive just like their road transport counterparts. Therefore, the passengers also often had to put up with verbal abuse and other forms of aggression.

As seen in Figure 5 the issue of safety was a problem to almost $60 \%$ of the commuters. Passengers were particularly at risk due to non-adherence to government regulation on provision of life jackets by most operators. Even when life jackets were provided they were often the cheapest ones in the market that were highly unreliable (Bayode \& Ipingbemi, 2016). There were also other serious risks attached to navigation on the Lagos lagoon such as collusion with other boats or floating logs and risk of fishing nets getting caught on propellers (Adeniyi, 2017). For instance, a boat mishap which resulted in the loss of many lives was attributed to poor visibility during a night journey (Punch, 2019). These hazards were particularly associated with night journeys which eventually made the State Government to ban night travel on the Lagos lagoon. Poor condition of vessels was also reflected in form of rickety boats, for instance it is not uncommon to find vessels leaking water while travelling on the waterway. The safety issue was further compounded by the problem of overloading and over speeding and other reckless behaviour. For instance, Bayode \& Ipingbemi (2016) attributed about $70 \%$ of accidents on the Lagos waterways to human error. There was also the problem of hyacinths which often clog waterways, affecting engines and making it difficult to navigate.

The high cost of water transport when compared to road mode of transport in Lagos State was attributed to factors such as low supply compared to the present demand for their services and high cost of maintenance of vessels (Nwakunor et al., 2016; Bayode \& Ipingbemi, 2016). While this observation may be true for some parts of the Lagos inland waterways, this conclusion cannot be deduced from this present study. This was because there was alow patronage in the area which could be seen from the low number of trips made by the available vessels. The most likely reason was probably the influence of union control which was usually very strong within the transport industry in the country. The transport unions often fixed rates and made their members abide through force and intimidation. High 
cost of transport may however be a great obstacle to widespread adoption of water transportation in the area, except measures are adopted to reduce cost of travel by this mode of transport.

\subsection{Possible Strategies to Improve Water Transportation in the Area}

Based on the findings of this study the following strategies are suggested: (1) to address the problems of gross inadequacy of terminal facilities and vessels for water transportation in the area, the Lagos State Government should invest more in inland water transportation. This will require the provision of more jetties and making abandoned ones functional. The State Government can also provide ferry services to this area and other routes not presently served by government ferry services. This will go a long way in improving the capacity of this mode of transport to facilitate movement and ensure access to more people in the area; (2) There is a need for the operators to acquire modern boats and ferries that will be more reliable, safe and also provide greater comfort in terms of seating and protection from the sun and rain. This will attract more people to travel by this mode of transportation; (3) Government should also provide incentives such as tax relief and as well as develop policies that would help facilitate access to credit for individuals and corporate organisations willing to invest in the this sub-sector. This will go a long way to attract investment in water transportation; (3) In addition, safety on the waterways can be improved through the strengthening of the Lagos Waterways Authority (LASWA), so that it can effectively perform the duty of enforcing safety regulations on the waterways.

Regulations such as the use of life jackets by all passengers and crew members, banning of night travels and adequate maintenance of vessels should be strictly enforced. This will help reduce the rate of accidents and fatalities often recorded; (4) Security is a major issue that must be addressed to improve water transportation in the area. Security on the waterways, areas around and within the jetties must be enforced to encourage more people to utilize this mode of transportation. In particular, car parking facilities around the jetties must be well protected so as to attract the patronage of car owners who commute partly on theroad; (5) There is also the need for public enlightenment on the need to adopt this mode of transportation, focusing on the advantages. This should mostly be directed at reducing the widespread sense of apathy concerning the use of water transport because of safety concerns among people in the area. 


\section{Conclusion}

This study examined inland water based transportation in the riverine parts of Ikorodu area of Lagos state. It was found that the capacity of water mode of transport was greatly reduced due to inadequate provision of jetties and other necessary facilities. Therefore, access to this mode was largely denied or made difficult for many people in the area. However, despite the poor infrastructure, water transport played an important role by enhancing mobility in the area. Particularly, it provided a fast and more sustainable means of movement within a city with a high level of road traffic congestion. In addition, the frequency of use by the commuters who travel by water is an indication that this mode of transport has a great potential of being adopted by a greater proportion of the population. However, relatively higher cost of journey compared to road travel, poor quality of vessels, safety related issues and poor security in the vicinity of jetties are the major obstacles that may discourage general adoption of water transportation in the area. Therefore, while water transportation has great potentials in the area, there is the need for greater attention from both government and the private sector, to significantly raise its capacity to fully compliment the road transport mode. This could be facilitated through a greater investment in water transport infrastructure and provision of modern vessels.

\section{Conflict of Interest}

The authors declare that there is no conflict of interest with any financial, personal, or other relationships with other people or organizations related to the material discussed in the article.

\section{References}

Adejare, Q.A; Olusina, J.O. and Olaleye, J.B. (2017). Empirically Determined Passenger Ferry Navigable Routes within Lagos Lagoon. Nigerian Journal of Technological Development, 14 (2): 74-79

Ademiluyi, I.A; Fashola, O.K. and Afolabi, O.J. (2016).Analysis of Intra-City Water Transportation in Lagos.International Journal of Innovative Research and Advanced Studies, 3 (8): 246-254

Adeniyi, K. (2017). "Lagos waterways passengers decry safety measures". Premium Times Online, November, 8, 2017.

Badejo, B. A. (2011).Transportation Removing the Clogs to Nigeria's Development. Anchorage Press and Publishers: Lagos, Nigeria 
Bassey, S. I. \& Nsa, M. E. (2018).Problems and Prospects of Developing Inland Water Transportation in Nigeria: The Case of Calabar River. IOSR Journal of Human and Social Sciences, 23 (7): 27-37

Bayode, T. \& Ipingbemi, O. (2016). Safety and Operational Characteristics of Water Based Transportation in Lagos State. SCIREA Journal of Traffic and Transportation Engineering, 1 (1): 13-31

Business Day Online (2018).“'Lagos commuters lose $75 \%$ of weekly working hours to traffic". December 1 $11^{\text {th }}$, 2018. Retrieved on 06/02/2019 from https://businessday.ng/news/article/lagos-commuters-lose-75-of-weekly-workinghours-to-traffic/

Christodoulou, A., Christidis, P., \& Bisselink, B. (2019). Forecasting the impacts of climate change on inland waterways. Transportation Research Part D: Transport and Environment, doi:10.1016/j.trd.2019.10.012

Chukwuma, O. M. (2014).The Characteristics of Inland Water Transport in Nigeria.IOSR Journal of Humanities and Social Science, 19 (3): 119-126.

Dai, B. L., Sheng, N., He, Y. L., Mu, F. H., Xu, J. M., \& Zhu, A. F. (2019). Development of an inland waterway traffic noise prediction model considering water surface adsorption and embankment shielding influences. International Journal of Environmental Science and Technology, 16(10), 5927-5936. doi:10.1007/s13762-01802186-2

Edelman, D.J. (2015).An Environmental Plan for Lagos, Nigeria. International Journal of Social Science, 3 (1): 201-279

Fellinda, L. (2006). World's Water Transport Needs Further Development. Transport and Development, 1: 68-72

Flugel, S. and Flotterod (2015).Traffic assignment for strategic transport model systems. Paper presented at International Transport Economics Association (ITEA) conference, June 17-19, 2015, University of Oslo, Oslo, Norway.

Gray, L. (2004).An Examination of the Problems of Water Transportation in Old Degama Province.Journal of Waterways, Africa, 33: 20-26

Hossain, N. U. I., Nur, F., Jaradat, R., Hosseini, S., Marufuzzaman, M., Puryear, S. M., \& Buchanan, R. K. (2019). Metrics for assessing overall performance of inland waterway ports: A bayesian network based approach. Complexity, 2019 doi:10.1155/2019/3518705

Hoyle, B.S. (1993). Water Transport and Urban Development: Some Geographical Perspectives and Propositions. Geojournal, 31 (4): 439-448

Iamtrakul, P., \& Wongbumru, T. (2019). Exploring eco-friendly travel towards sustainable water transport in bangkok. Paper presented at the IOP Conference Series: Earth and Environmental Science, , 398(1) doi:10.1088/1755-1315/398/1/012014 
Iamtrakul, P., Raungratanaamporn, I., \& Klaylee, J. (2018). Contribution on water transportation for resilient and sustainable lowland cities. Lowland Technology International, 20(3), 341-350

International Association of Public Transport (2013).Waterborne Transport, a Unique Contribution to Enhancing Mobility for Cities on Water. A Position Paper of Waterborne Transport Committee May 2013.

Kurniasari, E. and Pramesty, D.A. (2018).The Effects of Vehicle Intensity in Sumbersari Jember Regency.Geosfera Indonesia, 3 (3): 50-58

Łapko, A., \& Panasiuk, A. (2019). Water tourism as a recipient of transport services on the example of szczecin. Paper presented at the Transportation Research Procedia, 39 290-299. doi:10.1016/j.trpro.2019.06.031

Ndikom, O.B.C. (2013). A Critical Assessment of the Inland Waterways Operation and Management on the Development of the Nigerian maritime Industry. Greener Journal of Environmental Management and Public Safety, 2 (2): 99-107

Nigerian Bureau of Statistics (2013).Annual Abstract of Statistics, 2011.Federal Government of Nigeria, Abuja. Retrieved on 11/06/19 from http://istmat.info/files/uploads/53129/annual_abstract_of_statistics_2011.pdf

Nigerian Bureau of Statistics (2018). 2017 Demographic Statistics Bulletin, May.

Nwakunor, G.A., Ajeluorou, A. and Salau, G. (2016). Lagos waterways: A hidden treasure untapped. Retrieved on 06/11/2018 from http://m.guardian.ng/features/weekend/lagos-waterways-a-hidden-trasureuntapped/

Ogunbajo, A.B., Akinpelu, T.A. and Odubela, C.A. (2017).The Prospects and Problems of Water Transportation in Lagos Metropolis.LASPOTECH Journal of Scientific, Engineering and Technology Research, 1 (1): 1-12

Punch (2019). 12 bodies recovered in Lagos boat mishap, five still missing. July $2^{\text {nd }}, 2019$. Retrieved on03/09/2019 from https://punchng.com/lagos-boat-accident-12-bodiesrecovered-five-still-missing/

Tanko, M., Cheemarkurthy, H., Hall Kihl, S., \& Garme, K. (2019). Water transit passenger perceptions and planning factors: A swedish perspective. Travel Behaviour and Society, 16, 23-30. doi:10.1016/j.tbs.2019.02.002

Tannum, M. S., \& Ulvensøen, J. H. (2019). Urban mobility at sea and on waterways in norway. Paper presented at the Journal of Physics: Conference Series, , 1357(1) doi:10.1088/1742-6596/1357/1/012018

Tobias, M. S. G., Ramos, R. A. R., \& Rodrigues, D. S. (2019). Use of waterway transport integrated to urban transportation systems in amazonian cities: A vision of sustainable mobility. WIT Transactions on Ecology and the Environment, 238, 615-625. doi:10.2495/SC190531 
Usman Bolaji Abdulkadir and Animashaun Kikelomo Halimat / GEOSI Vol 5 No 1 (2020) 127-146

Wiercx, M., van Kalmthout, M., \& Wiegmans, B. (2019). Inland waterway terminal yard configuration contributing to sustainability: Modeling yard operations. Research in Transportation Economics, 73, 4-16. doi:10.1016/j.retrec.2019.02.001 